\title{
6.2 Діагностика адаптаційних можливостей юнаків-спринтерів до спеціалізованих навантажень в підготовчих періодах річного циклу тренування на етапах багаторічного вдосконалення
}

Аналіз передової практики спорту і результатів досліджень, проведених останніми роками, дозволяє стверджувати, що основним резервом вдосконалення системи спортивної підготовки $є$ розробка і впровадження наукових основ її управління. Ефективність управління процесом спортивного тренування на будь-якому етапі багаторічної підготовки пов'язана 3 чітким кількісним вираженням структури тренувальної і змагальної діяльності, характерній для конкретної дисципліни того або іншого виду спорту. Найголовніше завдання управління - постійне збалансування програми тренування із станом і можливостями юного спортсмена. Нині особливого значення набула та частина управління, яка повинна забезпечувати оптимальну відповідність між функціональними можливостями юного спортсмена i навантаженням від одного тренувального дня. Щоб розміряти щоденне тренувальне навантаження 3 можливостями юного спортсмена, потрібно регулярно проводити і оцінювати діагностику його відновлення [441 ; 442; 443; $444 ; 445]$.

Підготовка, що проводиться з урахуванням індивідуальних особливостей юних спортсменів, дозволяє якнайповніше проявити їх здібності і природні завдатки. Проте індивідуальність атлета може бути плідно виражена тільки у рамках загальних станів, що визначають раціональні форми побудови тренування. Слід підкреслити, що, незважаючи на очевидну науково-теоретичну і практичну значущість, проблема вдосконалення організації тренувального процесу у великих тренувальних циклах не стала ще предметом досить великої кількості досліджень. На думку Л. П. Матвєєва $(1972,1991)$ і О. М. Воробйова (1986), К. П. Сахновського (1998) це пояснюється частково тим, що цілісна структура тренування в річному циклі є об'єктом надзвичайної складності, який майже не піддається лабораторному вивченню i вимагає довготривалих досліджень в реальних умовах спортивної практики [445, с. 6]. Потрібні нові 
педагогічні технології, засновані на біологічному моделюванні людини, як індивідуальній особині. Вони дозволяють відкрити нові підходи до сучасних інновацій управління підготовкою юних бігунів з урахуванням об'єктивнішої реалізації принципу спортивної «індивідуалізації». Побудова тренувального процесу у спортсменів в річному циклі повинна здійснюватися за принципом зв'язано-послідовного перманентного планування і реалізації навантаження.

Планування тренування юних спортсменів на основі сучасних методичних концепцій і управління нею на основі даних про стан працездатності спортсменів визначають нині науковий підхід до тренерської практики на будь-яких етапах багаторічної підготовки [447, с. 8, с. 9]. При цьому прогрес в юнацькому спорті, як правило, обумовлений оптимізацією контролю учбово-тренувального процесу і управління цим процесом на основі адекватної оцінки стану органів і систем, визначальних і лімітуючих загальну і спеціальну працездатність юного спортсмена [450].

Вивчення процесу управління руховою діяльністю юних легкоатлетівспринтерів особливо актуально, оскільки підготовка вітчизняних висококваліфікованих бігунів на короткі дистанції залишає бажати кращого. Останнє багато в чому визначається раціональною і ефективною підготовкою юних спринтерів. Організація спортивної тренування вимагає усебічних i глибоких знань про суть тренувального процесу - його зміст і структуру, закономірності, що визначають побудову цього процесу i зміну його спрямованості із зростанням майстерності спортсменів [441, с. 11, с. 12, с. 13, с. 14 ].

Зв'язок між станом спортсмена i тренувальним навантаженням надзвичайно складно опосередкований, залежить від багатьох чинників i визначається великою кількістю змінних. Об'єктивних даних, що характеризують цей зв'язок, поки дуже мало. Правильне рішення цього питання дозволить тренерам, використовуючи педагогічні методи, домагатися раціональної і ефективної організації тренувального навантаження для юнаків- 
спринтерів 3 метою збереження і поліпшення їх працездатності [451, с. 15, с. 16, c. 17].

У науково-методичній літературі питання розвитку адаптації юних бігунів на короткі дистанції до тренувальних навантажень доки ще недостатньо освітлені. 3 цієї причини традиційно прийнята система організації тренувального процесу в річному циклі у юних спортсменів різного віку вимагає переосмислення в плані двох або одноциклової структури її побудови [458, с. 19]. Тому актуальним напрямом вивчення оптимізації тренувального процесу юних бігунів на короткі дистанції $є$ дослідження i обгрунтування педагогічних i функціональних критеріїв в оцінці ефективності відновних мікроциклів підготовчих періодів.

\subsubsection{1 Динаміка зміни показників рухової функції під впливом відновних мікроциклів підготовчих періодів у юнаків-спринтерів 14-15 років}

Об'єктивні відомості про зміст і спрямованість відновних процесів після тренування дають надійну основу i для пошуку засобів прискорення відновлення, і для такого чергування навантажень, які зможуть полегшити, прискорити течію відновних процесів $[460$, с. 21, с. 22, с. 23]. 3 метою вдосконалення індивідуальної підготовки юнаків-спринтерів на дистанціях 100200 м в роботі була прийнята технологія ефективного педагогічного контролю у рамках етапного i поточного обстеження. Передбачасться, ицо знання закономірності адаптації юних спортсменів до спеціалізованих навантажень дозволять тренерам ефективніше $і$ раціонально організовувати тренувальний процес в підготовчих періодах, де, як відомо, повинні закладатися позитивні довгострокові відставлені тренувальні ефекти (ДОТЕ) з урахуванням збереження здоров'я і нормального фізичного розвитку юнаків. 
На першому етапі педагогічного експерименту була проаналізована динаміка зміни дев'яти показників рухової функції під впливом відновних мікроциклів двох підготовчих періодів: сили згиначів стопи, стрибка по Абалакову, диференціювання станової сили, коефіцієнта активності бігового кроку, потужності дихання (ПТХМ), затримки дихання (проби Штангє і Гєнчі), часу стартової реакції, тремора і диференціювання почуття часу.

У цих дослідженнях показники рухової функції реєструвалися на початку і кінці кожного відновного мікроциклу, запланованого тренерами. На термін двох підготовчих періодів річного тренування було представлено для дослідження вісім розвантажувально-відновних мікроциклів, які щомісячно завершували серію трьох тренувальних, починаючи з вересня по квітень місяці. В результаті експериментальних досліджень було відмічено, що різні показники по-різному визначають міру адаптації юних спортсменів впродовж тривалого періоду часу (табл. 1).

\subsubsection{1. Зміни педагогічних показників рухової функції у юнаків-спринтерів молодшого віку}

3 чотирьох педагогічних показників рухової функції юних спринтерів 1415 років (сили згиначів стопи, стрибка по Абалакову, диференціювання станової сили і коефіцієнта активності бігового кроку) жоден показник, під впливом восьми відновних мікроциклів двох підготовчих періодів, не має негативних значень. Динаміка кожного 3 них характеризується своєю специфічною тенденцією розвитку. Так, наприклад, такий показник, як сила згиначів стопи 3 кінця вересня по кінець квітня має хвилеподібну тенденцію змін (з $\Delta x_{1}=8,4 \%$ у вересні до $\Delta x_{8}=5,0 \%$ - в квітні), що знижується, 3 двома періодами позитивного зростання в жовтні і березні $\left(\Delta x_{2}=9,9 \%\right.$ і $\left.\Delta x_{7}=7,6 \%\right)$ і одним періодом відносної стабілізації $\left(\Delta x_{4}=7,6 \%, \Delta x_{5}=7,3 \%, \Delta x_{6}=7,5 \%\right)$ в грудні-лютому місяцях (рис. 1 , табл. 1). 


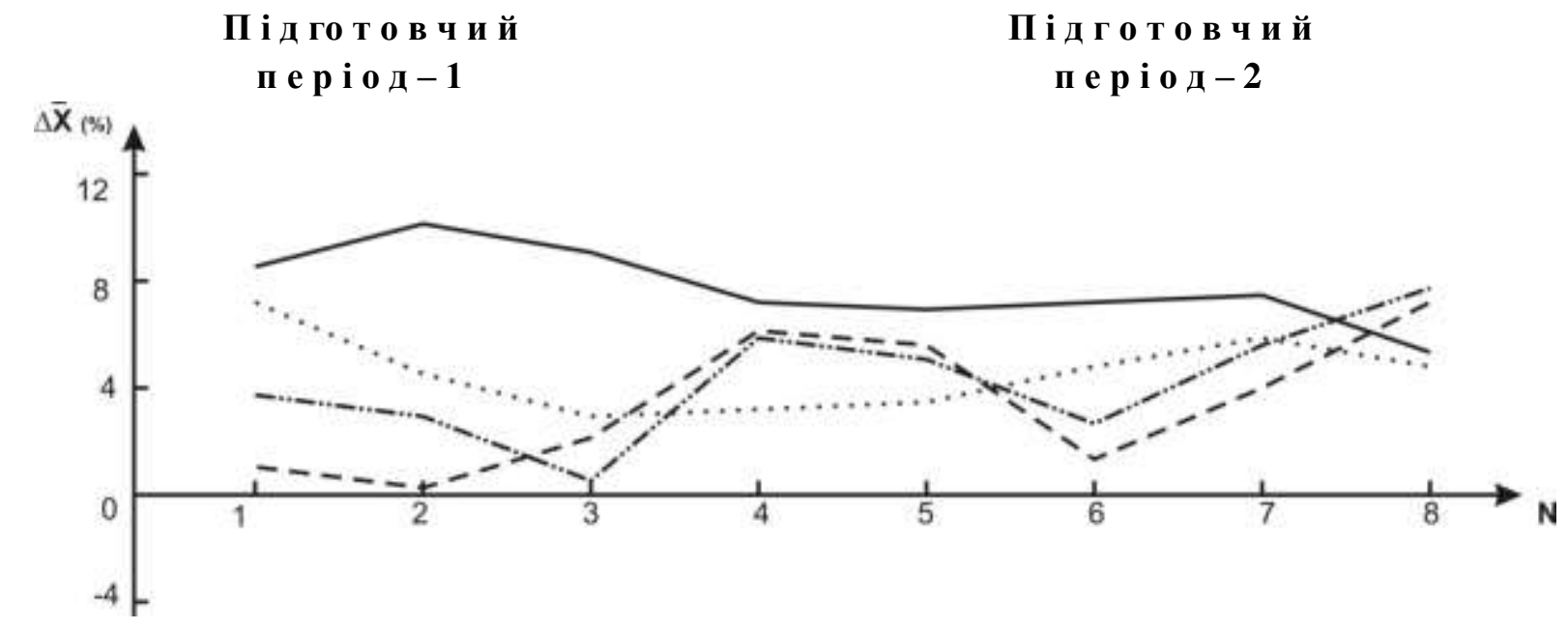

В ідновні мікроцикли

Рисунок 1. Динаміка зміни педагогічних показників, які визначають рухову функцію юнаків-спринтерів 14-15 років у підготовчих періодах цілорічного тренування.

Умовні позначки: — сила згиначів стопи; стрибок по Абалакову; - - - . диференціювання станової сили; - - - к коефіцієнт активності бігового кроку.

Динаміка зміни стрибка по Абалакову упродовж періоду часу, що вивчається, має тенденцію схожу з попереднім показником, але 3 нижчими значеннями приросту. Тривале зниження приросту цього показника 3 кінця вересня по кінець листопада місяця $\left(\Delta x_{1}=6,8 \%, \Delta x_{2}=4,6 \%, \Delta x_{3}=3,0 \%\right)$ змінюється двомісячною стабілізацією його в грудні-січні на рівні $\Delta x_{4}=3,2 \%$ i $\Delta x_{5}=3,4 \%$. Надалі, до кінця березня, відмічена ділянка значнішого приросту цього показника під впливом шостого і сьомого відновних мікроциклів $\left(\Delta x_{6}\right.$ $=4,75 \%$ i $\left.\Delta x_{7}=5,8 \%\right)$. А впродовж квітня зафіксовано зниження приросту показника до $\Delta x_{8}=4,5 \%$, при $p<0,05$.

Хвилеподібність коефіųiєнта активності бігового кроку відбиває позитивну, контрастнішу частоту хвиль в зміні значень цього показника під впливом восьми відновних мікроциклів двох підготовчих періодів. Значні зниження динаміки зміни цього показника по абсолютних величинах відмічені на двох ділянках - у кінці листопада і у кінці лютого $\left(\Delta x_{3}=0,6 \%\right.$ i $\Delta x_{6}=2,9 \%$, при $p<0,05)$. 
Схожу 3 коефіцієнтом активності бігового кроку тенденцію хвилеподібності представляє позитивна динаміка зміни диференціювання станової сили. Ділянки значного зниження динаміки зміни цього показника зафіксовані у кінці жовтня ( $\left.\Delta x_{2}=0,2 \%\right)$ і у кінці лютого $\left(\Delta x_{6}=1,4 \%\right)$, при $p<0,05$.

Таким чином, динаміка зміни чотирьох педагогічних показників рухової функції в процесі відновних мікроциклів двох підготовчих періодів юнаківспринтерів 14-15 років, окрім виявлення закономірності розвитку адаптації, вказує і про посилення інформативності цих показників в якості попередніх

Таблиця 1. Динаміка зміни педагогічних показників рухової функції в процесі відновних мікроциклів підготовчих періодів юнаків-спринтерів 14-15 років ( $\mathrm{n}=10)$

\begin{tabular}{|c|c|c|c|c|}
\hline \multirow{2}{*}{ Показники } & \multicolumn{4}{|c|}{ Відновні мікроцикли } \\
\hline & 1 & 2 & 3 & 4 \\
\hline Сила згиначів стопи, кг & $72,81 \pm 3,76$ & $72,30 \pm 3,73$ & $70,72 \pm 3,67$ & $73,60 \pm 3,34$ \\
\hline$\overline{\mathrm{X}} \pm \sigma$ & $78,97 \pm 4,08$ & $79,45 \pm 4,09$ & $76,80 \pm 4,04$ & $79,12 \pm 4,08$ \\
\hline$\Delta \overline{\mathrm{X}}$ & 6,16 & 7,15 & 6,08 & 5,52 \\
\hline Середьогруп. приріст, \% & 8,4 & 9,9 & 8,6 & 7,5 \\
\hline $\begin{array}{c}\text { Стрибок вгору по } \\
\text { Абалакову, } c \text { м }\end{array}$ & $42,72 \pm 3,21$ & $41,58 \pm 3,11$ & $43,11 \pm 3,24$ & $43,81 \pm 3,30$ \\
\hline$\overline{\mathrm{X}} \pm \sigma$ & $45,62 \pm 3,54$ & $43,49 \pm 3,29$ & $44,40 \pm 3,49$ & $45,21 \pm 3,62$ \\
\hline$\Delta \overline{\mathrm{X}}$ & 2,90 & 1,91 & 1,29 & 1,40 \\
\hline Середньогруп. приріст, \% & 6,8 & 4,6 & 3,0 & 3,2 \\
\hline $\begin{array}{l}\text { Диференціювання } \\
\text { станової сили, кट }\end{array}$ & $6,150 \pm 0,44$ & $6,220 \pm 0,45$ & $5,750 \pm 0,41$ & $5,690 \pm 0,40$ \\
\hline$\overline{\mathrm{X}} \pm \sigma$ & $6,058 \pm 0,42$ & $6,208 \pm 0,45$ & $5,635 \pm 0,40$ & $5,349 \pm 0,39$ \\
\hline$\Delta \overline{\mathrm{X}}$ & 0,092 & 0,012 & 0,115 & 0,341 \\
\hline Середньогруп. приріст, \% & 1,5 & 0,2 & 2,0 & 6,0 \\
\hline $\begin{array}{c}\text { Коефіцієнт активності } \\
\text { бігового кроку, у.o. }\end{array}$ & $1,240 \pm 0,091$ & $1,240 \pm 0,090$ & $1,240 \pm 0,091$ & $1,250 \pm 0,092$ \\
\hline$\overline{\mathrm{X}} \pm \sigma$ & $1,286 \pm 0,095$ & $1,277 \pm 0,094$ & $1,247 \pm 0,093$ & $1,320 \pm 0,111$ \\
\hline$\Delta \overline{\mathrm{X}}$ & 0,046 & 0,037 & 0,007 & 0,072 \\
\hline Середньогруп. приріст, \% & 3,75 & 3,0 & 0,6 & 5,75 \\
\hline
\end{tabular}


Продовження табл. 1

\begin{tabular}{|c|c|c|c|c|}
\hline \multirow{2}{*}{ Показники } & \multicolumn{4}{|c|}{ Відновні мікроцикли } \\
\hline & 5 & 6 & 7 & 8 \\
\hline Сила згиначів стопи, кг & $73,28 \pm 3,91$ & $71,14 \pm 3,69$ & $72,50 \pm 3,74$ & $73,08 \pm 3,89$ \\
\hline$\overline{\mathrm{X}} \pm \sigma$ & $78,62 \pm 4,07$ & $76,47 \pm 4,04$ & $78,01 \pm 4,07$ & $76,73 \pm 4,05$ \\
\hline$\Delta \overline{\mathrm{X}}$ & 5,34 & 5,33 & 5,51 & 3,65 \\
\hline Середньогруп. приріст, \% & 7,3 & 7,5 & 7,6 & 5,0 \\
\hline $\begin{array}{c}\text { Стрибок вгору по } \\
\text { Абалакову, } c \text { M }\end{array}$ & $40,92 \pm 3,07$ & $40,45 \pm 3,08$ & $41,93 \pm 3,13$ & $43,29 \pm 3,22$ \\
\hline$\overline{\mathrm{X}} \pm \sigma$ & $42,31 \pm 3,15$ & $42,37 \pm 3,17$ & $44,36 \pm 3,48$ & $45,23 \pm 3,41$ \\
\hline$\Delta \overline{\mathrm{X}}$ & 1,39 & 1,92 & 2,43 & 1,94 \\
\hline Середньогруп. приріст, \% & 3,4 & 4,75 & 5,8 & 4,5 \\
\hline $\begin{array}{l}\text { Диференціювання } \\
\text { станової сили, к2 }\end{array}$ & $5,510 \pm 0,39$ & $6,070 \pm 0,43$ & $6,330 \pm 0,47$ & $6,110 \pm 0,43$ \\
\hline$\overline{\mathrm{X}} \pm \sigma$ & $5,207 \pm 0,38$ & $5,986 \pm 0,42$ & $6,077 \pm 0,48$ & $5,671 \pm 0,40$ \\
\hline$\Delta \overline{\mathrm{X}}$ & 0,303 & 0,084 & 0,253 & 0,439 \\
\hline Середньогруп. приріст, \% & 5,5 & 1,4 & 4,0 & 7,2 \\
\hline $\begin{array}{l}\text { Коефіцієнт активності } \\
\text { бігового кроку, у.o. }\end{array}$ & $1,220 \pm 0,086$ & $1,250 \pm 0,093$ & $1,210 \pm 0,084$ & $1,190 \pm 0,077$ \\
\hline$\overline{\mathrm{X}} \pm \sigma$ & $1,281 \pm 0,094$ & $1,286 \pm 0,095$ & $1,280 \pm 0,093$ & $1,283 \pm 0,094$ \\
\hline$\Delta \overline{\mathrm{X}}$ & 0,061 & 0,036 & 0,07 & 0,093 \\
\hline Середньогруп. приріст, \% & 5,0 & 2,9 & 5,8 & 7,8 \\
\hline
\end{tabular}

критеріїв ефективності розвантажувальних мікроциклів до кінця кожного 3

періодів. Необхідно відмітити, що сила згиначів стопи і стрибок по Абалакову, унаслідок значніших змін у відновних мікроциклах, можуть мати абсолютну інформативність упродовж усіх восьми місяців підготовки юних спринтерів молодшої вікової групи (див. табл. 1, рис. 1). Проте слід сказати, що в той час, коли інформативність сили згиначів стопи і стрибка по Абалакову до кінця кожного з підготовчих періодів частково знижується, інформативність диференціювання станової сили і коефіцієнта активності бігового кроку значно зростає. У кінці другого підготовчого періоду в квітні місяці інформативність усіх чотирьох педагогічних показників ставати приблизно однаково значимою. На це вказує зближення кривих в період восьмого відновного мікроциклу. 


\subsubsection{2. Зміни фізіологічних показників руховій функції у юнаків- спринтерів молодшої вікової групи}

Про системні механізми адаптації до фізіологічних навантажень можна судити тільки на основі усебічного обліку сукупності реакцій цілісного організму, включаючи реакції з боку ЦНС, рухового і гормонального апаратів, серцево-судинною і дихальною систем, аналізаторів обміну речовин та ін. Не може бути якогось одного показника, що відбиває адаптаційні зміни в організмі - придатний лише комплекс показників, що характеризують діяльність різних органів і систем [444, с. 24, с. 25$]$.

У роботі була проаналізована динаміка п'яти фізіологічних показників рухової функції юнаків-спринтерів 14-15 років, що визначають працездатність юних спортсменів. Реєструвалися швидкість рухової реакції на слуховий аналізатор, тремор мускулатури ніг, потужність вдиху-видиху, затримка дихання на вдиху-видиху i диференціювання почуття часу. 3 п'яти фізіологічних показників рухової функції упродовж двох підготовчих періодів лише один показник - часу затримки дихання під впливом восьми відновних мікроциклів не має негативних значень (табл. 2; рис. 2).

Проби Штанге і Генчі впродовж першого підготовчого періоду проявляють хвилеподібну прогресуючу тенденцію з незначними зниженнями приросту у кінці листопада (на 0,27\% порівняно з жовтнем) і у кінці січня і лютого (на 1,35\% порівняно з груднем). Лише з кінця лютого по кінець квітня на всьому протязі другого підготовчого періоду динаміка носить безперервну позитивну тенденцію ( $\left.\Delta x_{6}=1,25 \% ; \Delta x_{7}=2,82 \% ; \Delta x_{8}=2,85 \%\right)$. Абсолютні значення цього показника вигідно відрізняються від інших, що вказує на його достатню попередню інформативність, особливо в останні три місяці підготовки (див. рис. 2).

Динаміка зміни показника потужності дихання має сходжу тенденцію 3 попереднім показником, але зі значнішим спадом середньогрупових значень в іншому і третьому відновних мікроциклах кінця жовтня і кінця листопада місяців (на 0,76\% порівняно з вереснем). Слід зазначити, що під впливом 3-го відновного 
мікроциклу (у кінці листопада) значення пневмотахометрії зафіксовані 3 негативним знаком $\left(\Delta x_{3}=-0,26 \%\right)$. Це вказує на факт помітної напруги адаптації юних бігунів до навантажень, визначальних даний показник. У інший же період часу тенденція характеризується позитивною динамікою ( на 2,26\% у кінці січня порівняно 3 листопадом і на 0,55 \% у кінці березня порівняно 3 лютим) лише 3 двома ділянками відносної стабілізації $\left(\Delta x_{6}=1,20 \%\right.$ i $\left.\Delta x_{8}=1,73 \%\right)$ у кінці лютого і в кінці квітня місяця (при $p<0,01)$.

Таблиця 2. Динаміка зміни фізіологічних показників рухової функції в процесі відновних мікроциклів підготовчих періодів юнаків-спринтерів 14-15 років (n $=10)$

\begin{tabular}{|c|c|c|c|c|}
\hline \multirow{2}{*}{ Показники } & \multicolumn{4}{|c|}{ Відновні мікроцикли } \\
\hline & 1 & 2 & 3 & 4 \\
\hline Затримка дихання, сек & $96,100 \pm 4,32$ & $96,640 \pm 4,435$ & $96,430 \pm 4,435$ & $96,970 \pm 4,438$ \\
\hline$\overline{\mathrm{X}} \pm \sigma$ & $96,820 \pm 4,436$ & $97,867 \pm 4,446$ & $97,394 \pm 4,442$ & $99,491 \pm 4,455$ \\
\hline$\Delta \overline{\mathrm{X}}$ & 0,720 & 1,227 & 0,964 & 2,521 \\
\hline Середньогруп. приріст,\% & 0,75 & 1,27 & 1,0 & 2,6 \\
\hline Пневмотахометрія, $л / c$ & $5,230 \pm 0,310$ & $5,150 \pm 0,305$ & $4,910 \pm 0,290$ & $4,840 \pm 0,285$ \\
\hline$\overline{\mathrm{X}} \pm \sigma$ & $5,256 \pm 0,308$ & $5,163 \pm 0,305$ & $4,897 \pm 0,388$ & $4,876 \pm 0,387$ \\
\hline$\Delta \overline{\mathrm{X}}$ & 0,026 & 0,013 & $-0,013$ & 0,036 \\
\hline Середньогруп. приріст, \% & 0,5 & 0,25 & $-0,26$ & 0,75 \\
\hline Тремор, $\boldsymbol{M M}^{2}$ & $10,740 \pm 1,093$ & $10,890 \pm 1,096$ & $11,310 \pm 1,207$ & $11,350 \pm 1,157$ \\
\hline$\overline{\mathrm{x}}+\sigma$ & $10,633 \pm 1,09$ & $10,765 \pm 1,09$ & $11,226 \pm 1,20$ & $11,418 \pm 1,16$ \\
\hline & 5 & 5 & 6 & 3 \\
\hline$\Delta \overline{\mathrm{X}}$ & 0,107 & 0,125 & 0,084 & $-0,068$ \\
\hline Середньогруп. приріст,\% & 1,0 & 1,15 & 0,75 & $-0,6$ \\
\hline Час стартової реакції,, с & $186,00 \pm 10,73$ & $185,00 \pm 10,72$ & $187,00 \pm 10,76$ & $185,00 \pm 10,72$ \\
\hline$\overline{\mathrm{X}} \pm \sigma$ & $\mid 184,88 \pm 10,72$ & $183,61 \pm 10,60$ & $187,94 \pm 10,77$ & $\mid 185,49 \pm 10,72$ \\
\hline$\Delta \overline{\mathrm{X}}$ & 1,116 & 1,387 & $-0,935$ & $-0,499$ \\
\hline Середньогруп. приріст,\% & 0,6 & 0,75 & $-0,5$ & $-0,27$ \\
\hline $\begin{array}{l}\text { Диференціювання } \\
\text { чувства часу, сек }\end{array}$ & $0,660 \pm 0,043$ & $0,690 \pm 0,042$ & $0,720 \pm 0,047$ & $0,610 \pm 0,041$ \\
\hline$\overline{\mathrm{X}} \pm \sigma$ & $0,663 \pm 0,041$ & $0,694 \pm 0,044$ & $0,721 \pm 0,047$ & $0,610 \pm 0,039$ \\
\hline$\Delta \overline{\mathrm{X}}$ & $-0,003$ & $-0,004$ & $-0,001$ & - \\
\hline Середньогруп. приріст,\% & $-0,4$ & $-0,55$ & $-0,2$ & 0,00 \\
\hline
\end{tabular}


Продовження табл. 2

\begin{tabular}{|c|c|c|c|c|}
\hline \multirow{2}{*}{ Показники } & \multicolumn{4}{|c|}{ Відновні мікроцикли } \\
\hline & 5 & 6 & 7 & 8 \\
\hline Затримка дихання, сек & $96,520 \pm 4,434$ & $95,890 \pm 4,430$ & $96,780 \pm 4,436$ & $98,240 \pm 4,447$ \\
\hline$\overline{\mathrm{X}} \pm \sigma$ & $98,209 \pm 4,447$ & $97,088 \pm 4,440$ & $99,509 \pm 4,463$ & $101,039 \pm 4,460$ \\
\hline$\Delta \overline{\mathrm{X}}$ & 1,689 & 1,198 & 2,729 & 2,799 \\
\hline Середньогруп. приріст,\% & 1,75 & 1,25 & 2,82 & 2,85 \\
\hline Пневмотахометрія,,$/ c$ & $4,820 \pm 0,284$ & $4,870 \pm 0,287$ & $4,890 \pm 0,288$ & $4,970 \pm 0,301$ \\
\hline$\overline{\mathrm{X}} \pm \sigma$ & $4,880 \pm 0,387$ & $|4,928 \pm 0,391|$ & $4,975 \pm 4,493$ & $5,055 \pm 0,502$ \\
\hline$\Delta \overline{\mathrm{X}}$ & 0,060 & 0,058 & 0,085 & 0,085 \\
\hline Середньогруп. прирост, \% & 1,25 & 1,2 & 1,75 & 1,73 \\
\hline Тремор, $\boldsymbol{M M}^{2}$ & $11,670 \pm 1,183$ & $11,720 \pm 1,185$ & $11,700 \pm 1,184$ & $11,680 \pm 1,183$ \\
\hline$\overline{\mathrm{X}} \pm \sigma$ & $11,658 \pm 1,18$ & $11,685 \pm 1,18$ & $11,618 \pm 1,18$ & $11,532 \pm 1,17$ \\
\hline$\Delta \overline{\mathrm{X}}$ & 0,012 & 0,035 & 0,082 & 0,148 \\
\hline Среднегруп. приріст, \% & 0,1 & 0,3 & 0,7 & 1,27 \\
\hline Час стартової реакції,, с & $186,00 \pm 10,73$ & $186,50 \pm 10,74$ & $187,00 \pm 10,76$ & $187,0 \pm 10,76$ \\
\hline$\overline{\mathrm{X}} \pm \sigma$ & $\mid \begin{array}{c}185,52 \pm 10,7 \\
4\end{array}$ & $\mid \begin{array}{c}186,13 \pm 10,7 \\
3\end{array}$ & $\begin{array}{c}185,60 \pm 10,7 \\
2\end{array}$ & $\begin{array}{c}185,45 \pm 10,7 \\
2\end{array}$ \\
\hline$\Delta \overline{\mathrm{X}}$ & 0,484 & 0,373 & 1,403 & 1,552 \\
\hline Середньогруп. приріст, \% & 0,26 & 0,20 & 0,75 & 0,83 \\
\hline $\begin{array}{l}\text { Диференціювання } \\
\text { почуття часу, сек }\end{array}$ & $0,580 \pm 0,037$ & $0,709 \pm 0,048$ & $0,650 \pm 0,042$ & $0,600 \pm 0,040$ \\
\hline$\overline{\mathrm{X}} \pm \sigma$ & $0,581 \pm 0,038$ & $0,708 \pm 0,047$ & $0,649 \pm 0,043$ & $0,602 \pm 0,041$ \\
\hline$\Delta \overline{\mathrm{X}}$ & $-0,001$ & 0,001 & $-0,001$ & $-0,002$ \\
\hline Середньогруп. приріст,\% & $-0,25$ & 0,1 & $-0,2$ & $-0,28$ \\
\hline
\end{tabular}

Швидкість реакиії на слуховий аналізатор має деяку інформативність як показник рухової функції лише в першому, другому, сьомому і восьмому відновних мікроциклах, оскільки позитивні зміни його під впливом цих мікроциклів мають істотніші значення у кінці вересня, жовтня, березня і квітня місяців $\left(\Delta x_{1}=0,6 \%, \Delta x_{2}=0,75 \%, \Delta x_{7}=0,75 \%\right.$ і $\left.\Delta x_{8}=0,83 \%\right)$, при $p<0,05$. У решту часу цей показник не має достатньої інформативності, щоб його враховувати при програмуванні тренувального процесу у відновних мікроциклах юних спринтерів 14-15 років ( $\left.\Delta x_{3}=-0,5 \%, \Delta x_{4}=-0,27 \%, \Delta x_{5}=0,26 \%, \Delta x_{6}=0,20 \%\right)$ при недотриманні достовірності відмінностей тільки в 5-му і 6-му відновних мікроциклах. 


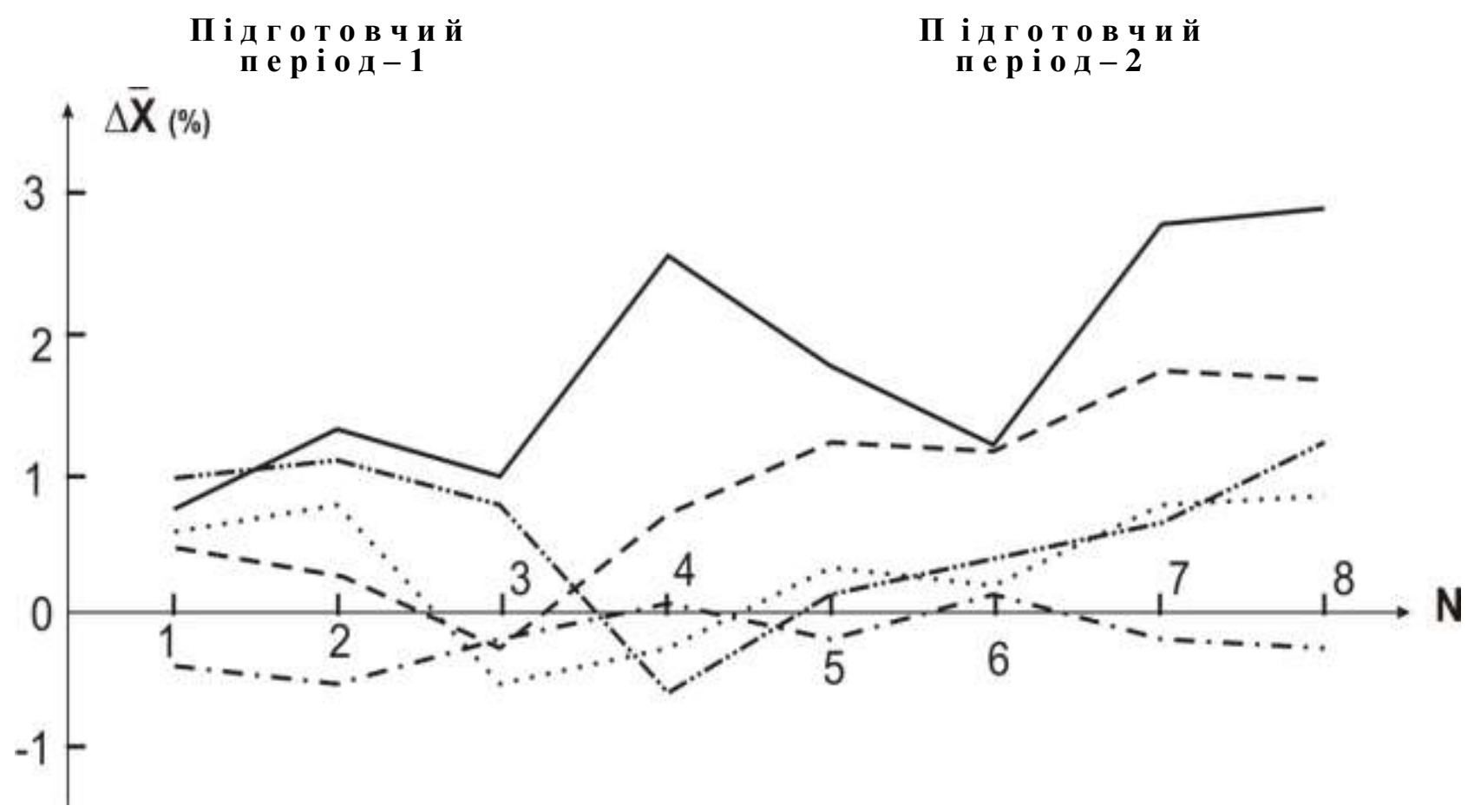

В і д но в н і м ікроцикли

Рисунок 2. Динаміка зміни функціональних показників, які визначають рухову функцію юнаків-спринтерів 14-15 років у підготовчих періодах річного циклу.

Умовні позначки:

— затримка дихання; - - - - потужність вдиху-видиху; - - - - д диференціювання почуття часу; - - - тремор; час реакції слухового аналізатору.

Тремор, як показник рухової функції має трохи більшу інформативність, ніж попередній показник в першому, другому, третьому, сьомому і восьмому відновних мікроциклах $\left(\Delta x_{1}=1,2 \%, \Delta x_{2}=1,35 \%, \Delta x_{3}=0,75 \%, \Delta x_{7}=0,7 \%, \Delta x_{8}\right.$ $=1,27 \%$ ) - по тих же термінах, що і швидкість рухової реакції, плюс додатково і у кінці листопада місяця. В період четвертого, п'ятого і шостого відновних мікроциклів 3 кінця грудня по кінець лютого інформативність цього показника занадто мала ( $\left.\Delta x_{4}=-0,6 \%, \Delta x_{5}=0,1 \%, \Delta x_{6}=0,3 \%\right)$. Як і у попереднього показника швидкості реакції, інформативність тремора починає зростати тільки до закінчення другого підготовчого періоду (див. рис. 2).

Диференціювання почуття часу на протязі двох підготовчих періодів під впливом восьми відновних мікроциклів змінюється занадто незначно $\left(\Delta x_{1}=-\right.$ $0,4 \%, \Delta x_{2}=-0,55 \%, \Delta x_{3}=-0,2 \%, \Delta x_{4}=0,00 \%, \Delta x_{5}=-0,25 \%, \Delta x_{6}=0,1 \%, \Delta x_{7}$ 
$\left.=-0,2 \%, \Delta x_{8}=-0,28 \%\right)$, що вказує на його абсолютну неінформативність в якості критеріїв оцінки ефективності відновних мікроциклів (при $p<0,05$ ).

\subsubsection{3. Узагальнення результатів педагогічних досліджень у юнаків-спринтерів учбово-тренувальної групи 3-4 року навчання}

В результаті завершення досліджень відносно зміни педагогічних показників рухової функції під впливом відновних мікроциклів двох підготовчих періодів у юних бігунів на короткі дистанції 14-15 років, встановлено, що значення кривих сили згиначів стопи і стрибка по Абалакову, як більше інформативних показників, у кінці другого підготовчого періоду відповідають рівню значень нижчих, ніж на початку першого підготовчого періоду $\left(\Delta x_{1}=8,4 \%\right.$ i $\Delta x_{8}=5,0 \%$ - сила згиначів стопи; $\Delta x_{1}=6,8 \%$ i $\Delta x_{8}=4,5 \%$ - стрибок по Абалакову), при $p<0,01$.

А значення кривих диференціювання станової сили і коефіцієнту активності бігового кроку в кінці другого підготовчого періоду підлягають рівню значень більш високих, ніж на початку року $\left(\Delta x_{1}=1,5 \%\right.$ i $\Delta x_{8}=7,2 \%$ диференціювання станової сили; $\Delta x_{1}=3,75 \%$ и $\Delta x_{8}=7,8 \%$ - коефіцієнт активності бігового кроку), при $p>0,05$ тіки в п’ятому відновному мікроциклі. Очевидно, в цьому простежуються adanmaціï до навантажень, що визначають одні показники і переадапmaціï до навантажень, визначальних інші.

Дворазове зближення кривих педагогічних показників у своєрідний пучок у кінці кожного підготовчого періоду (5-й і 8-й відновні мікроцикли) підтверджує ту обставину, що адаптація до цих показників у бігунів до закінчення періодів проходить як би завершальний цикл. Проте нижчі значення приросту сили згиначів стопи і стрибка по Абалакову у кінці другого підготовчого періоду в порівнянні з початком року вказують про зниження розвитку адаптації юних спортсменів до навантажень, що визначають ці показники до цього терміну часу. Цей результат підтверджують наші ранні дослідження по обгрунтуванню динаміки працездатності юних бігунів 14-15 
років в підготовчих періодах річного циклу тренування, в яких був відмічений факт напруги процесу адаптації за умови організації їх підготовки по двох цикловій системі $[455$, с. 26$]$.

Помічено також, що розширений спектр «кривих» на початку кожного 3 підготовчих періодів, очевидно, вказує на тимчасову втрату адаптації юних бігунів молодшої вікової групи до навантажень, що визначають ці педагогічні показники. Але, якщо на початку першого підготовчого періоду така втрата адаптації цілком з'ясовна, то на початку другого - зниження адаптації, це результат нераціонально вибраної періодизації юнацької підготовки для молодшої вікової групи.

Проаналізувавши динаміку зміни фізіологічних показників рухової функції у юнаків-спринтерів 14-15 років, можна відмітити, що до цих показників розвиток процесу адаптації упродовж двох підготовчих періодів проходить так само в два етапи, як і до педагогічних (див. рис. 1, 2). Вужчий спектр графічних кривих на початку першого підготовчого періоду (кінець вересня) вказує на ті обставини, що в цей період часу у юних спортсменів спостерігається ще не закінчений процес загасання спеціальної працездатності після літнього періоду змагання і тренувань в серпні місяці в спортивному таборі.

3 п'яти фізіологічних показників рухової функції юних спринтерів 14-15 років найбільшу інформативність упродовж двох підготовчих періодів має тільки показник затримки дихання (проби Штангє і Генчі), у якого позитивні зміни носять прогресуючий хвилеподібний характер. Інформативність таких показників, як пневмотахометрії, тремора і часу стартової реакції упродовж тривалого часу носить непостійний характер. На початку року упродовж двох місяців (1-й, 2-й відновні мікроцикли) незначну інформативність мають усі три показники і лише один показник, тремора залишається досить інформативним $і$ в подальшому місяці - у кінці листопада (3-й відновний мікроцикл). Слід зазначити, що до закінчення першого підготовчого періоду (з 4-го відновного мікроциклу) i увесь подальший час інформативність показника пневмотахометрії зростає і утримується на досить помітному рівні. А показники 
тремора і часу стартової реакції придбавають інформативність лише у кінці другого підготовчого періоду (7-й і 8-й відновні мікроцикли).

Динаміка змін показника диференціювання почуття часу, під впливом восьми відновних мікроциклів, не маючи істотних відмінностей до і після їх закінчення, вказує на неінформативність цього показника в плані обліку його при організації i програмуванні тренувального навантаження у відновних мікроциклах підготовчих періодів цілорічного тренування юнаків-спринтерів 14-15 років. А широкий спектр графічних кривих у кінці другого підготовчого періоду, напередодні травня місяця, свідчить про незавершений процес адаптації юних спринтерів до навантажень, що визначають їх фізіологічні показники рухової функції (див. рис. 2). Є усі підстави припускати, що розвиток адаптації до цих навантажень у юних бігунів завершиться пізніше, в літньому періоді змагання. Але для цього потрібні додаткові дослідження.

\subsubsection{2. Показники рухової функції і їх динаміка в процесі відновних мікроциклів підготовчих періодів юних бігунів на короткі дистанції 16-17 років}

Із-за великої різноманітності засобів спортивного тренування при оцінці роботи, виконаної тим або іншим спортсменом, часто виникають великі труднощі. Тренер в цьому випадку інтуїтивно стає на шлях порівняння одного спортсмена з іншим. Цей метод є скрутним, оскільки зіставлення йде за багатьма параметрами: по деяких з них навантаження вище у одного спортсмена, а по інших у іншого. Крім того, з позицій чітких кількісних оцінок існуючі поняття «велике», «середнє», «мале» навантаження є достатньою мірою умовними [449, с. 27]. Виникає необхідність у вивченні особливостей адаптації до спеціальних навантажень юнаків-спринтерів різного віку, а далі у формуванні чітких якісних і кількісних еталонів по кожному провідному параметру навантаження, пошуку надійних критеріїв побудови не лише тренувальних, але і відновних мікроциклів. 


\subsubsection{1. Зміни педагогічних показників рухової функції у юнаків-спринтерів старшої вікової групи}

У юнаків-спринтерів 16-17 років так само, як і 14-15 літніх бігунів, жоден педагогічний показник не має негативних значень зміни під впливом восьми відновних мікроциклів двох підготовчих періодів (див. рис. 1, 3).

Сила згиначів стопи 3 кінця вересня по кінець квітня показує не дуже вираженою позитивну динаміку (з 11,1\% у вересні до 11,3\% у кінці квітня) 3 однією лише ділянкою ( $\Delta x_{3}=9,8 \%$ проти $\Delta x_{2}=11,49 \%$ в листопаді місяці), де зафіксований зворотній характер (рис. 3, табл. 3).
П і д г о то в ч и й
п е р і о д- 1
П і дг о то в ч и й
пе р і о д-2

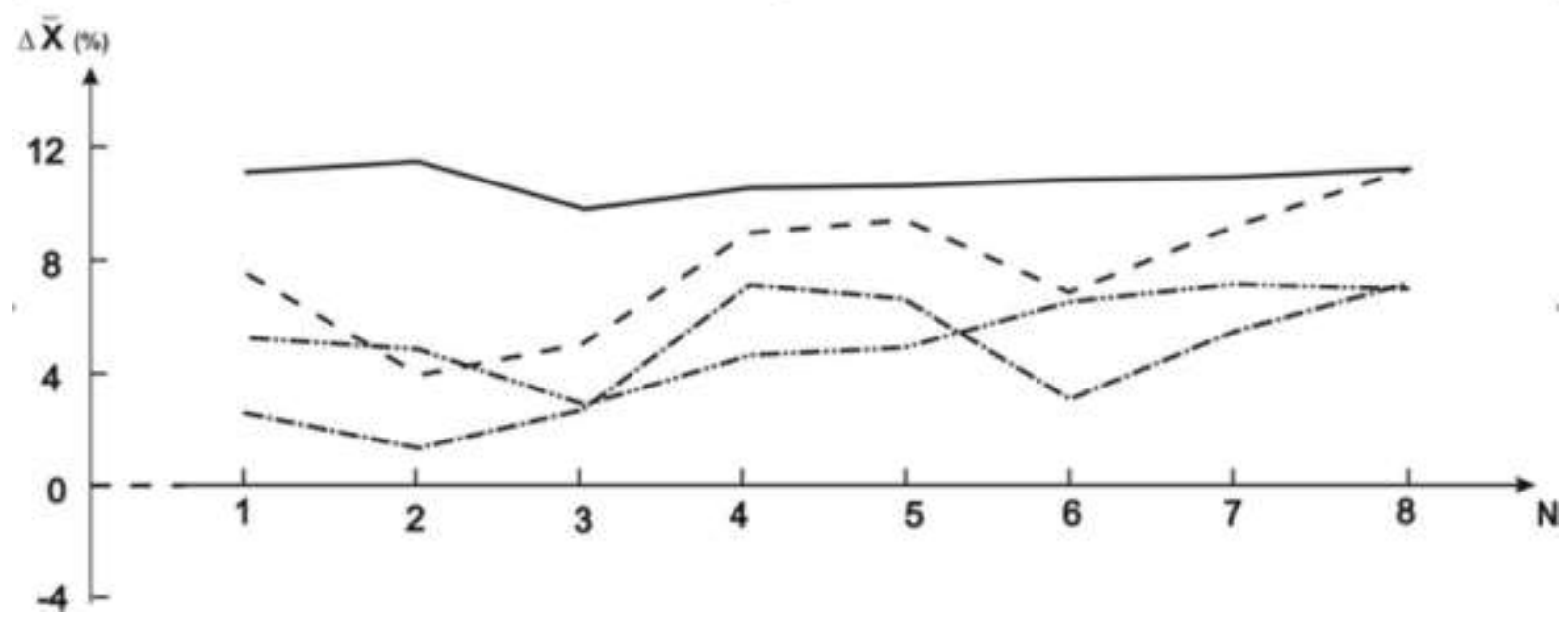

В ід н о в н і м і кроцикли

Рисунок 3. Динаміка зміни педагогічних показників, які визначають рухову функцію юнаків-спринтерів 16-17 років в підготовчих періодах річного циклу

Умовні позначки: — - сила згиначів стопи; - - - -стрибок по Абалакову; -. - - - д диференціювання станової сили; - - - ко коефіцієнт активності бігового кроку.

Динаміка змін стрибка по Абалакову упродовж двох підготовчих періодів носить хвилеподібний характер з тенденцією деякого зростання позитивної різниці цього показника до закінчення другого підготовчого періоду. Відмічені 
лише дві ділянки зниження - 3 кінця вересня по кінець жовтня $\left(\Delta x_{1}=7,7 \%\right.$ i $\left.\Delta x_{2}=4,0 \%\right)$, при $p<0,01$ і з кінця січня після закінчення лютого $\left(\Delta x_{5}=9,4 \%\right.$ і $\Delta x_{6}$ $=6,9 \%)$, при $p>0,05$.

Коефіиієнт активності бігового кроку має схожу тенденцію з попереднім показником: від першого у вересні до третього мікроциклу у листопаді $\left(\Delta x_{1}\right.$ $\left.=5,4 \% ; \Delta x_{2}=4,8 \% ; \Delta x_{3}=2,7 \%\right)$ і від сьомого у березні до восьмого в квітні $\left(\Delta x_{7}\right.$ $\left.=7,2 \% ; \Delta x_{8}=7,0 \%\right)$ відмічені позитивні зміни у бік зниження динаміки. У решту

Таблиця 3. Динаміка зміни педагогічних показників рухової функції в процесі відновних мікроциклів підготовчих періодів юнаків-спринтерів 16-17 років (n $=10)$

\begin{tabular}{|c|c|c|c|c|}
\hline \multirow{2}{*}{ Показники } & \multicolumn{4}{|c|}{ Відновні мікроцикли } \\
\cline { 2 - 5 } & 1 & 2 & 3 & 4 \\
\hline Сила згиначів стопи, к2 & $104,90 \pm 7,03$ & $104,50 \pm 7,02$ & $95,60 \pm 6,92$ & $106,14 \pm 7,05$ \\
$\overline{\mathrm{X}} \pm \sigma$ & $116,54 \pm 7,07$ & $116,51 \pm 7,05$ & $104,96 \pm 7,01$ & $117,28 \pm 7,08$ \\
$\Delta \overline{\mathrm{X}}$ & 11,64 & 12,01 & 9,36 & 11,14 \\
Середньогруп. приріст, \% & 11,1 & 11,5 & 9,8 & 10,5 \\
\hline Стрибок вгору по & $55,64 \pm 3,41$ & $54,37 \pm 3,65$ & $56,12 \pm 4,09$ & $57,28 \pm 4,78$ \\
Абалакову,см & $59,92 \pm 6,13$ & $56,54 \pm 4,50$ & $58,70 \pm 5,88$ & $62,43 \pm 6,09$ \\
$\overline{\mathrm{X}} \pm \sigma$ & 4,28 & 2,17 & 2,58 & 4,03 \\
$\Delta \overline{\mathrm{X}}$ & 7,7 & 4,0 & 4,6 & 9,0 \\
\hline ередньогруп. приріст, \% & & 4,0 & \\
\hline Диференціювання станової & $4,030 \pm 0,37$ & $2,420 \pm 0,21$ & $2,020 \pm 0,19$ & $1,910 \pm 0,17$ \\
сили,кг & $3,930 \pm 0,35$ & $2,394 \pm 0,22$ & $1,966 \pm 0,18$ & $1,792 \pm 0,15$ \\
$\overline{\mathrm{X}} \pm \sigma$ & 0,100 & 0,026 & 0,054 & 0,118 \\
$\Delta \overline{\mathrm{X}}$ & 2,5 & 1,1 & 2,7 & 6,2 \\
\hline Середньогруп. приріст, \% & 2,5 & & \\
\hline Коефіцієнт активності & $1,27 \pm 0,094$ & $1,27 \pm 0,095$ & $1,27 \pm 0,094$ & $1,28 \pm 0,095$ \\
бігового кроку, у.о. & $1,34 \pm 0,113$ & $1,33 \pm 0,111$ & $1,30 \pm 0,097$ & $1,34 \pm 0,112$ \\
$\overline{\mathrm{X}} \pm \sigma$ & 0,07 & 0,06 & 0,03 & 0,06 \\
$\Delta \overline{\mathrm{X}}$ & 5,4 & 4,8 & 2,7 & 4,7 \\
\hline \hline
\end{tabular}


Продовження табл. 3

\begin{tabular}{|c|c|c|c|c|}
\hline \multirow{2}{*}{ Показники } & \multicolumn{4}{|c|}{ Відновні мікроцикли } \\
\hline & 5 & 6 & 7 & 8 \\
\hline Сила згиначів стопи, кг & $104,64 \pm 7,02$ & $103,61 \pm 6,94$ & $105,82 \pm 7,01$ & $107,65 \pm 7,07$ \\
\hline$\overline{\mathrm{X}} \pm \sigma$ & $115,67 \pm 7,07$ & $114,69 \pm 7,08$ & $117,24 \pm 7,09$ & $119,81 \pm 7,10$ \\
\hline$\Delta \overline{\mathrm{X}}$ & 11,03 & 11,08 & 11,42 & 12,16 \\
\hline Середньогруп. приріст, \% & 10,55 & 10,7 & 10,8 & 11 , \\
\hline $\begin{array}{c}\text { Стрибок вгору по } \\
\text { Абалакову,см }\end{array}$ & $52,96 \pm 3,82$ & $52,65 \pm 3,75$ & $56,71 \pm 4,41$ & $58,01 \pm 5,90$ \\
\hline$\overline{\mathrm{X}} \pm \sigma$ & $57,93 \pm 4,64$ & $|56,28 \pm 4,53|$ & $61,98 \pm 5,22$ & $64,55 \pm 6,14$ \\
\hline$\Delta \overline{\mathrm{X}}$ & 4,97 & 3,63 & 5,27 & 6,54 \\
\hline Середньогруп. приріст, \% & 9,4 & 6,9 & 9,3 & 11,28 \\
\hline $\begin{array}{c}\text { Диференціювання станової } \\
\text { сили,кг }\end{array}$ & $2,740 \pm 0,24$ & $2,510 \pm 0,24$ & $2,050 \pm 0,21$ & $2,120 \pm 0,28$ \\
\hline $\bar{X} \pm \sigma$ & $2,587 \pm 0,26$ & $2,433 \pm 0,21$ & $1,933 \pm 0,17$ & $1,959 \pm 0,18$ \\
\hline$\Delta \overline{\mathrm{X}}$ & 0,153 & 0,077 & 0,117 & 0,161 \\
\hline Середньогруп. прирі & 5,6 & 3,1 & 5,7 & 7,6 \\
\hline $\begin{array}{c}\text { Коефіцієнт активності } \\
\text { бігового кроку, у.о. }\end{array}$ & $1,25 \pm 0,093$ & $1,28 \pm 0,095$ & $1,24 \pm 0,092$ & $1,24 \pm 0,091$ \\
\hline$\overline{\mathrm{X}} \pm \sigma$ & $1,31 \pm 0,098$ & $1,36 \pm 0,114$ & $1,33 \pm 0,112$ & $1,33 \pm 0,111$ \\
\hline$\Delta \overline{\mathrm{X}}$ & 0,06 & 0,08 & 0,09 & 0,09 \\
\hline Середньогруп. приріст, \% & 5,1 & 6,4 & 7,2 & 7,0 \\
\hline
\end{tabular}

часу - під впливом відновних мікроциклів грудня, січня і лютого місяців ці зміни спрямовані у бік збільшення динаміки приросту цього показника (див. рис. 3).

Позитивні зміни показника диференціювання станової сили з кінця вересня по кінець листопада місяців (перший - третій відновні мікроцикли) мають невисокі абсолютні величини: $\Delta x_{1}=2,5 \% ; \Delta x_{2}=1,1 \% ; \Delta x_{3}=2,7 \%$. Такий факт вказує про недостатньо високу інформативність цього показника на цьому відрізку часу. На подальших етапах підготовчих періодів значення цього показника зумовлюють велику інформативність його використання в якості попереднього критерію ефективності відновних мікроциклів в грудні, січні, лютому, березні і квітні місяцях: $\Delta x_{4}=6,2 \% ; \Delta x_{5}=5,6 \% ; \Delta x_{6}=3,1 \% ; \Delta x_{7}=5,7 \% ; \Delta x_{8}$ 
=7,6\% при недотриманні достовірності відмінностей тільки в п'ятому відновному мікроциклі (див. рис. 3).

Таким чином, 3 чотирьох педагогічних показників найбільш інформативними в плані використання їх для оцінки ефективності відновних мікроциклів двох підготовчих періодів, у юнаків-спринтерів 16-17 років виявилися показники сили згиначів стопи і стрибка по Абалакову. Значно меншу інформативність мають показники коефіцієнта активності бігового кроку i диференціювання станової сили. Причому інформативність цих двох показників збільшується до закінчення кожного підготовчого періоду (при $p<0,05$ ).

\subsubsection{2 Зміни фізіологічних показників рухової функції у юнаків-спринтерів 16-17 років}

У старшій віковій групі юнаків-спринтерів 3 п'яти перелічених вище функціональних фізіологічних показників рухової функції упродовж двох підготовчих періодів лише час стартової реакції і диференціювання почуття часу під впливом декількох відновних мікроциклів мають негативні значення. Цей факт свідчить про те, що процес адаптації у спринтерів 16-17 років до фізіологічних показників проходить сприятливіше, ніж у юнаків-спринтерів 1415 років (табл. 4 , рис. 4 ).

Показники часу затримки дихання на вдиху і видиху з кінця січня по кінець лютого і з кінця березня по кінець квітня мають тимчасову тенденцію до зниження динаміки зміни $\left(\Delta x_{5}=2,95 \% ; \Delta x_{6}=2,65 \%\right.$; і $\left.\Delta x_{7}=3,45 \% ; \Delta x_{8}=3,35 \%\right)$ порівняно з попередніми відновними мікроциклами, де вона має зростаючий характер (див. рис. 4).

Динаміка змін потужності дихання (пневмотахометрія) має лише одну ділянку незначного зниження під впливом шостого відновного мікроциклу ( $\Delta x_{6}$ $=3,1 \%$ ). У решту часу позитивна динаміка зміни показників пневмотахометрії характерна тенденції зростання з $\Delta x_{1}=0,5 \%$ до $\Delta x_{8}=3,45 \%$, при $p<0,01$. Такі результати свідчать про високу попередню інформативність цього показника 
рухової функції в якості критерію оцінки ефективності відновних мікроциклів на період з початку грудня по кінець квітня (при $p>0,05$ тільки в п'ятому відновному мікроциклі).

Тремор, як показник рухової функції юних спринтерів 16-17 років відбиває динаміку помірного хвилеподібного характеру 3 схожими значеннями на початку першого підготовчого періоду і у кінці другого ( $\Delta x_{1}=1,4 \%$ i $\left.\Delta x_{8}=1,0 \%\right)$, що, очевидно, вказує про не завершення процесу адаптації юних спортсменів до навантажень тих, що визначають цей показник (див. рис. 4).

Таблиця 4. Динаміка зміни фізіологічних показників рухової функції в процесі відновних мікроциклів підготовчих періодів юнаків-спринтерів 16-17 років (n=10)

\begin{tabular}{|c|c|c|c|c|}
\hline \multirow{2}{*}{ Показники } & \multicolumn{4}{|c|}{ Відновні мікроцикли } \\
\hline & 1 & 2 & 3 & 4 \\
\hline Затримка дихання, сек & $103,54 \pm 6,85$ & $105,41 \pm 7,02$ & $103,67 \pm 6,87$ & $107,39 \pm 7,09$ \\
\hline$\overline{\mathrm{X}} \pm \sigma$ & $104,78 \pm 6,77$ & $107,307 \pm 6,96$ & $105,847 \pm 6,89$ & $111,041 \pm 7,17$ \\
\hline$\Delta \overline{\mathrm{X}}$ & 1,242 & 1,897 & 2,177 & 3,651 \\
\hline Середньогруп. приріст,\% & 1,2 & 1,8 & 2,1 & 3,4 \\
\hline Пневмотахометрія, $л / c$ & $5,51 \pm 0,61$ & $5,46 \pm 0,59$ & $5,62 \pm 0,62$ & $5,63 \pm 0,65$ \\
\hline$\overline{\mathrm{X}} \pm \sigma$ & $5,537 \pm 0,63$ & $5,552 \pm 0,64$ & $5,726 \pm 0,66$ & $5,782 \pm 0,67$ \\
\hline$\Delta \overline{\mathrm{X}}$ & 0,027 & 0,092 & 0,106 & 0,152 \\
\hline Середньогруп. приріст, \% & 0,5 & 1,7 & 1,9 & 2,7 \\
\hline Тремор, $\boldsymbol{M M}^{2}$ & $7,61 \pm 0,83$ & $7,52 \pm 0,82$ & $7,56 \pm 0,85$ & $7,43 \pm 0,78$ \\
\hline$\overline{\mathrm{X}} \pm \sigma$ & $7,504 \pm 0,81$ & $7,407 \pm 0,80$ & $7,507 \pm 0,83$ & $7,374 \pm 0,77$ \\
\hline$\Delta \overline{\mathrm{X}}$ & 0,106 & 0,113 & 0,053 & 0,056 \\
\hline Середньогруп. приріст,\% & 1,4 & 1,5 & 0,7 & 0,75 \\
\hline Час стартової реакції,,$м c$ & $162,77 \pm 8,07$ & $167,23 \pm 8,75$ & $160,30 \pm 8,09$ & $161,26 \pm 8,05$ \\
\hline$\overline{\mathrm{X}} \pm \sigma$ & $161,387 \pm 8,04$ & $164,889 \pm 8,07$ & $161,021 \pm 8,06$ & $160,937 \pm 8,07$ \\
\hline$\Delta \overline{\mathrm{X}}$ & 1,383 & 2,341 & $-0,721$ & 0,323 \\
\hline Середньогруп. приріст,\% & 0,85 & 1,4 & $-0,45$ & 0,2 \\
\hline $\begin{array}{l}\text { Диференціювання } \\
\text { чувства часу, сек }\end{array}$ & $0,48 \pm 0,025$ & $0,51 \pm 0,027$ & $0,561 \pm 0,029$ & $0,43 \pm 0,019$ \\
\hline$\overline{\mathrm{X}} \pm \sigma$ & $0,482 \pm 0,026$ & $0,511 \pm 0,028$ & $0,56 \pm 0,029$ & $0,431 \pm 0,02$ \\
\hline$\Delta \overline{\mathrm{X}}$ & $-0,002$ & $-0,001$ & 0,001 & $-0,001$ \\
\hline Середньогруп. приріст,\% & $-0,5$ & $-0,3$ & 0,25 & $-0,35$ \\
\hline
\end{tabular}


Продовження табл. 4

\begin{tabular}{|c|c|c|c|c|}
\hline \multirow{2}{*}{ Показники } & \multicolumn{4}{|c|}{ Відновні мікроцикли } \\
\cline { 2 - 5 } & 5 & 6 & 7 & 8 \\
\hline Затримка дихання, сек & $103,61 \pm 7,01$ & $104,9 \pm 6,88$ & $105,1 \pm 6,90$ & $104,6 \pm 6,84$ \\
$\overline{\mathrm{X}} \pm \sigma$ & $106,66 \pm 7,09$ & $107,679 \pm 7,13$ & $108,725 \pm 7,15$ & $108,104 \pm 7,14$ \\
$\Delta \overline{\mathrm{X}}$ & 3,056 & 2,779 & 3,625 & 3,504 \\
Середньогруп. приріст, $\%$ & 2,95 & 2,65 & 3,45 & 3,35 \\
\hline Пневмотахометрія, $л / c$ & $5,92 \pm 0,71$ & $5,75 \pm 0,66$ & $5,68 \pm 0,64$ & $5,78 \pm 0,68$ \\
$\overline{\mathrm{X}} \pm \sigma$ & $6,109 \pm 0,73$ & $5,928 \pm 0,70$ & $5,864 \pm 0,69$ & $5,979 \pm 0,71$ \\
$\Delta \overline{\mathrm{X}}$ & 0,189 & 0,178 & 0,184 & 0,199 \\
Середньогруп. приріст, $\%$ & 3,2 & 3,1 & 3,25 & 3,45 \\
\hline Тремор, мм & $7,43 \pm 0,81$ & $7,48 \pm 0,81$ & $7,51 \pm 0,82$ & $7,42 \pm 0,78$ \\
$\overline{\mathrm{X}} \pm \sigma$ & $7,46 \pm 0,79$ & $7,391 \pm 0,79$ & $7,412 \pm 0,79$ & $7,346 \pm 0,77$ \\
$\Delta \overline{\mathrm{X}}$ & 0,030 & 0,089 & 0,098 & 0,074 \\
Середньогруп. приріст, $\%$ & 0,4 & 1,2 & 1,3 & 1,0 \\
\hline Час стартової реакції, $м c$ & $158,25 \pm 7,96$ & $159,8 \pm 7,90$ & $160,7 \pm 8,10$ & $156,8 \pm 7,82$ \\
$\overline{\mathrm{X}} \pm \sigma$ & $157,775 \pm 7,88$ & $159,001 \pm 7,85$ & $159,093 \pm 7,88$ & $154,918 \pm 7,77$ \\
$\Delta \overline{\mathrm{X}}$ & 0,475 & 0,799 & 1,607 & 1,882 \\
Середньогруп. приріст,\% & 0,3 & 0,5 & 1,0 & 1,2 \\
\hline Диференціювання & $0,4 \pm 0,018$ & $0,55 \pm 0,028$ & $0,51 \pm 0,026$ & $0,41 \pm 0,017$ \\
чувства часу, сек & & & & \\
$\overline{\mathrm{X}} \pm \sigma$ & $0,401 \pm 0,018$ & $0,549 \pm 0,028$ & $0,509 \pm 0,026$ & $0,407 \pm 0,017$ \\
$\Delta \overline{\mathrm{X}}$ & $-0,008$ & 0,001 & 0,001 & 0,003 \\
Середньогруп. приріст, \% & $-0,2$ & 0,2 & 0,1 & 0,75 \\
\hline
\end{tabular}

Подібну тенденцію відбиває і показник швидкості реакції на слуховий аналізатор, який під впливом третього відновного мікроциклу, у кінці листопада має негативну величину зміни $\left(\Delta x_{3}=-0,45 \%\right)$. Слід зауважити, що істотних відмінностей у величинах тремора і особливо швидкості реакції на слуховий аналізатор, починаючи з грудня по квітень місяць не спостерігається, що говорить про недостатню інформативну цінність цих двох показників в якості критеріїв оцінки ефективності відновних мікроциклів на цьому відрізку часу (при $p<0,01$ ).

Проте, прояв істотніших відмінностей до і після закінчення шостого, сьомого і восьмого відновних мікроциклів з кінця лютого по кінець квітня, очевидно, так само може вказувати про посилення попередньої. 


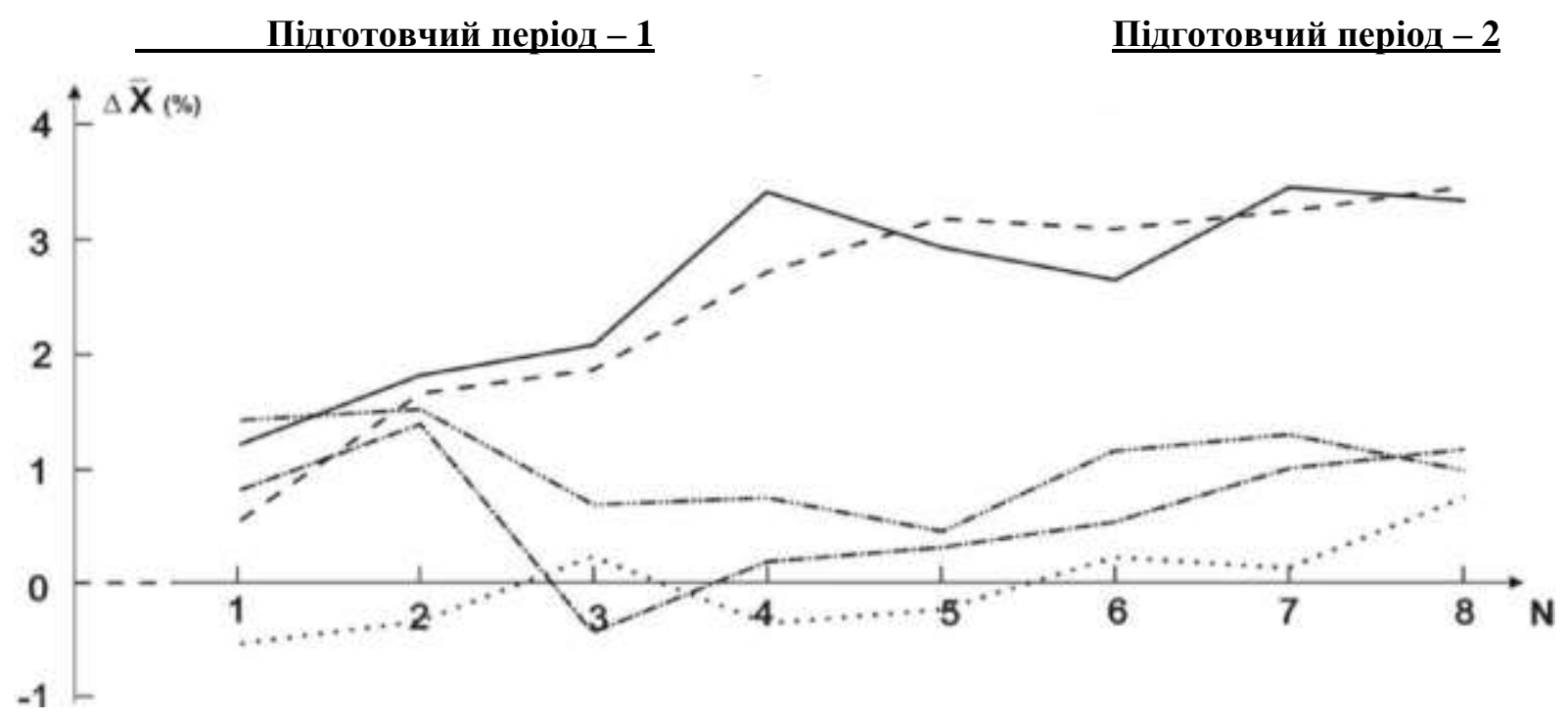

В ідн овні мікроцикли

Рисунок 4. Динаміка зміни функціональних показників, що визначають рухову функцію юнаків-спринтерів 16-17 років в підготовчих періодах річного циклу.

Умовні позначки: — затримка дихання; ---- потужность вдиху-видоху;

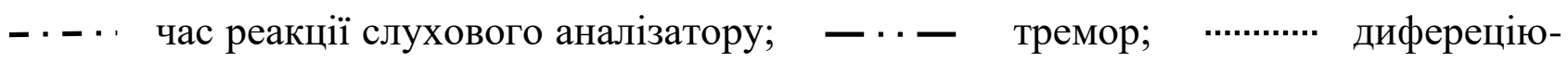
вання почуття часу.

інформативності цих показників напередодні літнього періоду змагань (див. рис. 4).

Показник диференціювання почуття часу під впливом восьми відновних мікроциклів упродовж двох підготовчих періодів змінюється украй з незначними величинами як в позитивному, так і в негативному напрямі $\left(\Delta x_{1}=-0,5 \% ; \Delta x_{2}=-\right.$ $\left.0,3 \% ; \Delta x_{3}=0,25 \% ; \Delta x_{4}=-0,35 \% ; \Delta x_{5}=-0,2 \% ; \Delta x_{6}=0,2 \% ; \Delta x_{7}=0,1 \% ; \Delta x_{8}=0,75 \%\right)$. Це вказує на його неінформативну і неефективність використання як критерію оцінки ефективності відновних мікроциклів підготовчих періодів (при $p<0,05$ ).

\subsubsection{3 Узагальнення результатів педагогічних досліджень}

\section{у юнаків-спринтерів групи спортивного вдосконалення}

Динаміка зміни педагогічних показників рухової функції у старших юнаків упродовж двох підготовчих періодів вказує на посилення інформативності їх не лише до кінця кожного з періодів, але і на усьому їх протязі. У свою чергу, це, 
очевидно, підтверджує сприятливіший розвиток процесу адаптації спортсменів цієї вікової групи до навантажень, що визначають ці показники. Потрібно відмітити, що в старшій віковій групі процес адаптації до педагогічних показників рухової функції розвивається один раз безперервно з вересня по квітень упродовж майже двох макроциклів. А зближення кривих до закінчення другого підготовчого періоду з величинами приросту більшими у кінці квітня, ніж у кінці вересня, початку першого підготовчого періоду, ймовірно, вказує на відносне завершення процесу адаптації у бігунів до навантажень педагогічного характеру.

Проаналізувавши зміни фізіологічних показників рухової функції у старших юнаків під впливом восьми відновних мікроциклів, встановлено, що процес адаптації у них проходить, як і до педагогічних, єдиний раз упродовж двох підготовчих періодів. Проте, широкий спектр кривих у кінці другого підготовчого періоду підтверджує незавершеність процесу адаптації юних спортсменів до навантажень, що визначають ці фізіологічні показники. Очевидно, як і у юнаків 14-15 років, передбачається, що розвиток адаптації до цих навантажень завершиться пізніше в літньому періоді змагання.

Математична обробка цифрового матеріалу цих наукових досліджень відносно рішення статистичної задачі - вплив зміни працездатності на зміни показників рухової функції, дозволила визначити рангову значущість дев'яти показників ефективності обліку програмування їх в різних відновних мікроциклах двох підготовчих періодів річного циклу тренування юнаківспринтерів середнього і старшого віку (табл. 5, 6).

На підставі діагностики адаптаційних можливостей юнаків-спринтерів до спеціалізованих навантажень в підготовчих періодах річного циклу тренування вдосконалення системи застосування педагогічних інноваційних засобів відновлення передбачає раціоналізацію тренувального процесу на основі науково-обгрунтованих методів планування ходу підготовки спортсменів в макро-, мезо- і мікроциклах. Тому пропонується система побудови річного 
циклу підготовки юнаків-спринтерів на основі технології зв'язанопослідовного планування і аналізу ефективності тренувального процесу кожного этапа-мезоцикла. Без аналізу і оцінки тренувального процесу на попередньому етапі немає, і не може бути зв'язано-послідовного (перманентного) ланцюга, який повинен вибудовувати логіку оптимізації цілорічного тренування юних спортсменів не лише у бігу на короткі дистанції, але, очевидно, і в інших видах спорту теж.

Таблиця 5. Таблиця функціональних критеріїв ефективності в першому відновному мікроциклі підготовчих періодів юнаків-спринтерів 14-15 років

\begin{tabular}{|c|c|c|c|c|c|c|c|c|c|c|c|}
\hline $\begin{array}{l}\text { ML } \\
\text { GR: } \\
\text { VM-1 }\end{array}$ & 1 & 2 & 3 & 4 & 5 & 6 & 7 & 8 & 9 & 10 & 11 \\
\hline 1 & 1,000 & & & & & & & & & & \\
\hline 2 & 0,169 & 1,000 & & & & & & & & & \\
\hline 3 & 0,212 & 0,226 & 1,000 & & & & & & & & \\
\hline 4 & 0,046 & 0,189 & 0,448 & 1,000 & & & & & & & \\
\hline 5 & $-0,387$ & $-0,068$ & 0,185 & 0,277 & 1,000 & & & & & & \\
\hline 6 & 0,0537 & $-0,059$ & $-0,598$ & $-0,486$ & 0,509 & 1,000 & & & & & \\
\hline 7 & $-0,104$ & $-0,289$ & $-0,649$ & $-0,159$ & $-0,107$ & 0,613 & 1,000 & & & & \\
\hline 8 & 0,23 & $-0,107$ & $-0,758$ & $-0,264$ & 0,219 & 0,753 & 0,519 & 1,000 & & & \\
\hline 9 & 0,375 & 0,428 & 0,033 & 0,22 & 0,37 & $-0,23$ & $-0,466$ & 0,259 & 1,000 & & \\
\hline 10 & 0,274 & 0,035 & 0,153 & 0,798 & $-0,117$ & $-0,24$ & $-0,086$ & 0,062 & 0,432 & 1,000 & \\
\hline 11 & 0,132 & $-0,649$ & $-0,233$ & $-0,196$ & 0,664 & 0,032 & 0,25 & 0,164 & $-0,268$ & $-0,108$ & 1,000 \\
\hline
\end{tabular}

Таблиця 6. Таблиця функціональних критеріїв ефективності в першому відновному мікроциклі підготовчих періодів юнаків-спринтерів 16-17 років

\begin{tabular}{|c|c|c|c|c|c|c|c|c|c|c|c|}
\hline $\begin{array}{l}\text { ST GR: } \\
\text { VM-1 }\end{array}$ & 1 & 2 & 3 & 4 & 5 & 6 & 7 & 8 & 9 & 10 & 11 \\
\hline 1 & 1,000 & & & & & & & & & & \\
\hline 2 & 0,135 & 1,000 & & & & & & & & & \\
\hline 3 & $-0,039$ & $-0,12$ & 1,000 & & & & & & & & \\
\hline 4 & $-0,18$ & 0,151 & $-0,166$ & 1,000 & & & & & & & \\
\hline 5 & $-0,022$ & $-0,093$ & 0,03 & 0,019 & 1,000 & & & & & & \\
\hline 6 & 0,014 & $-0,124$ & 0,312 & $-0,159$ & $-0,067$ & 1,000 & & & & & \\
\hline 7 & 0,106 & $0, \mathbf{3 2 8}$ & 0,553 & $-0,051$ & 0,099 & 0,198 & 1,000 & & & & \\
\hline 8 & $-0,131$ & $-0,162$ & $-0,086$ & 0,512 & 0,528 & 0,266 & 0,287 & 1,000 & & & \\
\hline 9 & 0,004 & $-0,11$ & $-0,224$ & $-0,147$ & 0,629 & $-0,642$ & $-0,393$ & $-0,171$ & 1,000 & & \\
\hline 10 & 0,351 & 0,052 & $-0,777$ & 0,206 & $-0,1$ & $-0,14$ & $-0,67$ & 0,055 & 0,098 & 1,000 & \\
\hline 11 & $-0,118$ & $-0,55$ & 0,608 & $-0,209$ & $-0,212$ & 0,504 & 0,422 & 0,151 & $-0,536$ & $-0,548$ & 1,000 \\
\hline
\end{tabular}

Умовні позначки: 1 - сила згиначів стопи; 2 - стрибок по Абалакову; 3 - час стартової реакції; 4 - тремор; 5 - диференціювання станової сили; 6 - потужність вдиху-видоху; 7 - коефіцієнт активності бігового кроку; 8 - затримка дихання; 9 - диференціювання почуття часу; 10 - загальна працездатність; 11 - спеціальна працездатність. 


\section{Висновки}

В результаті проведених досліджень по вивченню величини зміни педагогічних і фізіологічних показників рухової функції під впливом різних відновних мікроциклів підготовчих періодів цілорічного тренування юнаківспринтерів 14-17 років була визначена закономірність розвитку адаптації до спеціалізованих навантажень юних спортсменів молодшої і старшої юнацької вікової групи. Встановлено - чим вище відносно осі абцисс розташовані на графіках «криві» змін різних показників рухової функції під впливом відновних мікроциклів, тим сильніше прояв їх інформативності в оцінці ефективності розвантажувальних мікроциклів по відновленню втраченої працездатності юних бігунів різного віку в підготовчих періодах.

Встановлено, що серед чотирьох педагогічних показників рухової функції сила згиначів стопи і стрибок по Абалакову, під впливом восьми відновних мікроциклів в обох підготовчих періодах 3 вересня по квітень місяць мають більш високі позитивні зміни - від 3,0\% до 9,9\% у молодших юнаків і від 4,0 \% до 11,5 \% у старших. Значення таких результатів можуть вказувати на високу попередню інформативність цих показників рухової функції в оцінці ефективності і програмування тренувального процесу юнаків-бігунів на короткі дистанції 14-17 років в розвантажувальних відновних мікроциклах підготовчих періодів. Значно меншу інформативність мають показники коефіuієнта активності бігового кроку і диференціювання станової сили (від 0,2 до 7,8 \% i 1,1 до 7,6 \% відповідно в молодшій і старшій віковій групі). Інформативність цих двох показників збільшується до закінчення кожного підготовчого періоду.

Дворазове зближення графічних кривих у своєрідний пучок у кінці кожного підготовчого періоду (5-й і 8-й відновні мікроцикли) підтверджує ту обставину, що адаптація до педагогічних показників у бігунів обох вікових груп до закінчення періодів проходить як би завершальний цикл. Проте нижчі значення приросту сили згиначів стопи і стрибка по Абалакову в молодшій віковій групі у кінці другого підготовчого періоду, в порівнянні з початком року, 
вказують про зниження розвитку адаптації юних спортсменів до навантажень тих, що визначають ці показники до цього терміну часу.

Розширений спектр «кривих» (1,5-8,4\% i 1,4-7,5\% - молодша вікова група і 2,5-1 1,1\% і 3,1-10,7\% - старші юнаки) на початку кожного з підготовчих періодів (1-й і 6-й відновні мікроцикли), очевидно, говорить про тимчасову втрату адаптації юних бігунів обох вікових груп до навантажень, що визначають педагогічні показники після попередніх періодів змагань. Але, якщо на початку першого підготовчого періоду така втрата адаптації цілком з'ясовна для обох вікових груп, то на початку другого, ширша розбіжність між педагогічними показниками у юнаків 14-15 років - це результат значно гіршій їх адаптації, підтверджувальний факт про нераціонально вибрану періодизацію річної підготовки.

Якщо в молодшій віковій групі юнаків-спринтерів адаптація до навантажень, що визначають педагогічні показники юних спринтерів, проходить як би двічі до закінчення макроциклів, то в старшій групі процес адаптації розвивається один раз безперервно 3 вересня по квітень упродовж двох підготовчих періодів.

3 п'яти фізіологічних показників рухової функції юнаків-спринтерів 14-15 років (часу затримки дихання, потужності дихання, тремора, швидкості реакції на слуховий аналізатор, диференціювання почуття часу) найбільшу інформативність в оцінці ефективності відновних мікроциклів підготовчих періодів має час затримки дихання, у якого позитивні зміни під впливом восьми відновних мікроциклів носять прогресивний хвиле-подібний характер. Нижній рівень хвилі складає 0,75\% позитивного приросту (ВМ-1 у кінці вересня) а верхній - 2,85\% (ВМ-8 у кінці квітня місяця).

Другим за значимістю інформації є показник потужності дихання, у якого лише з кінця жовтня по кінець грудня-початку січня місяця зміни мають занадто низьку позитивну величину. А у кінці листопада після завершення розвантажувально-відновного мікроциклу середньостатистичні показники пневмотахометрії у молодших юнаків були навіть понижені на 0,26\% порівняно 
3 показниками початку відновного мікроциклу. У інший же період часу позитивні зміни потужності дихання під впливом подальших відновних мікроциклів були динамічніші (від 0,75 до 1,73\%).

Три інші показники - тремора, швидкості реакції на слуховий аналізатор і диференціювання почуття часу у молодших юнаків істотно не покращувалися після завершення більшості відновних мікроциклів. Показники часто погіршувалися порівняно 3 початковими середньостатистичними даними на початку відновних мікроциклів упродовж двох підготовчих періодів.

Проаналізувавши динаміку зміни фізіологічних показників рухової функції у юнаків-спринтерів 14-15 років, можна відмітити, що розвиток процесу адаптації до навантажень, що визначають ці показники упродовж двох підготовчих періодів проходить так само двічі, як i до раніше вивченим педагогічним. Широкий же спектр графічних кривих у кінці другого підготовчого періоду напередодні травня місяця свідчить про незавершений процес адаптації юних спринтерів до цих навантажень. $Є$ усі підстави припускати, що розвиток адаптації до цих навантажень у юних бігунів може завершитися в літньому періоді змагання. Для уточнення цього питання потрібні додаткові дослідження.

У юнаків-спринтерів 16-17 років 3 перелічених вище функціональних показників рухової функції упродовж двох підготовчих періодів лише час стартової реакиії і диференціювання почуття часу під впливом декількох відновних мікроциклів мають негативні зміни. Інші фізіологічні показники $є$ цілком інформативними для оцінки ефективності і програмування відновних мікроциклів. Проте з кінця березня (7-й і 8-й відновні мікроцикли) до завершення другого підготовчого періоду інформативність показника часу стартової реакції поступово зростає. Цей факт свідчить про те, що процес адаптації у старших юнаків до фізіологічних показників проходить сприятливіше, ніж у юнаків молодшої вікової групи. Висновок цілком узгоджується 3 дослідженнями, проведеними раніше по вивченню обгрунтування динаміки працездатності юнаків бігунів на короткі дистанції 14-15 і 16-17 років. 
Проаналізувавши динаміку зміни фізіологічних показників рухової функції під впливом восьми відновних мікроциклів у юнаків-спринтерів 16-17 років, встановлено, що процес адаптації у них проходить єдиний раз упродовж двох підготовчих періодів. Як і у молодшій віковій групі, широкий спектр кривих у кінці другого підготовчого періоду підтверджує незавершеність процесу адаптації юних спортсменів до навантажень, що визначають ці фізіологічні показники. Очевидно, як і у юнаків 14-15 років, передбачається, що розвиток адаптації до цих навантажень може завершитися в літньому періоді змагання.

Таким чином, при педагогічному контролі і управлінні тренувальним процесом юнаків-спринтерів середнього і старшого віку слід враховувати їх особливості адаптації до навантажень, що визначають педагогічні і фізіологічні показники рухової функції. Це дозволить тренерам раціонально і економно витрачати руховий потенціал за допомогою ефективного програмування $\mathrm{i}$ моделювання тренувального процесу не лише у відновних, але і тренувальних мікроциклах підготовчих періодів юних бігунів на короткі дистанції.

Достовірність відмінностей середніх арифметичних значень за деякими показниками рухової функції юнаків-спринтерів в обох вікових групах не дотримується лише в п'ятому відновному мікроциклі кінця січня місяця після завершення етапу зимових змагань. Очевидно, при необхідності вивчення подібних питань в періодах змагань потрібно проведення додаткових експериментальних досліджень.

Ці виведення цілком узгоджуються з концепцією основоположників теорії і методики вітчизняного спорту Л. П. Матвєєва і М. М. Яковлєва. Перший з них ще в 1965 році минулого століття писав, що біологічний процес не можна протиставляти педагогічному - вони єдині як за формою, так і за змістом; другий, в 1976 році стверджував - механізми управління тренувальним процесом можуть бути засновані тільки на знаннях законів адаптації людського організму. «Матеріальною» основою підвищення тренованості і спортивної результативності будь-якого спортсмена $є$ тренувальний процес, що базується на загальній теорії спорту, теорії і методиці обраного виду спорту і законах розвитку 
i адаптації людського організму. Закони адаптації визначають принципи i закономірності спортивно-педагогічного процесу. Незнання або неприйняття реально чинних законів адаптації обумовлює, у тому числі, множинне різночитання таких понять, як «тренованість» $\mathrm{i}$ «спортивна форма».

Подальші дослідження будуть спрямовані на узагальнення i систематизацію отриманих результатів з метою програмування і моделювання оптимального тренувального навантаження у відновних мікроциклах підготовчих періодів юнаків-спринтерів 14-17 років. 